\title{
Expanding the knowledge of plankton diversity of tropical lakes from the Northeast Colombian Andes
}

\author{
María I. Criales-Hernández ${ }^{1}$, Diana M. Sanchez-Lobo ${ }^{1}$ \& Johanna K. Almeyda Osorio ${ }^{1}$ \\ 1. Laboratorio de Hidrobiología, Escuela de biología, Facultad de Ciencias Básicas, Universidad Industrial de Santander, \\ Bucaramanga, Santander, Colombia; mcriales@uis.edu.co
}

\author{
Received 15-X-2019. Corrected 07-VIII-2020. Accepted 31-VIII-2020.
}

\begin{abstract}
Introduction: A large number of planktonic communities found in tropical lakes have not yet been recorded, limiting understanding of how these ecosystems function and of the role that organisms play within them. Objective: Add new records of previously described species and to contribute to the knowledge of the planktonic communities present in tropical mountain and lowland lakes of the northeast Colombian Andes. Methods: Planktonic samples were collected and physicochemical variables measured in nine tropical lakes. Organisms were identified and a bibliographic search was carried out in databases and research articles to the identification of the new records to Colombia. Results: We present the data corresponding to six physicochemical variables measured in tropical lakes of this region and expand the existing information on organisms present in tropical lakes with a list of 391 taxa (299 phytoplankton and 92 zooplankton). The proportion of planktonic species unique to tropical lakes and the low similarity between lake types found with a Jaccard analysis indicated high heterogeneity of ecological conditions in the studied lakes. Conclusions: The 391 taxa found and 15 new records contribute to the list of planktonic organisms present in tropical lakes located in high and low areas of the Colombian northeast Andes.
\end{abstract}

Key words: Plankton; aquatic ecosystems; lowland, mountain; richness; Colombia.

Criales-Hernández, M.I., Sanchez-Lobo, D.M., \& Almeyda Osorio, J.K. (2020). Expanding the knowledge of plankton diversity of tropical lakes from the Northeast Colombian Andes. Revista de Biología Tropical, 68(Suppl. 2), S159-S176.

There are 304 million lakes worldwide, covering approximately 402 million $\mathrm{km}^{2}$ of the continental terrestrial surface. Most of these ecosystems are geologically young; they are mainly of glacial, tectonic, volcanic, or fluvial origin (Hutchinson 1957; Downing et al., 2006). Lakes are not considered highly permanent features of the landscape, and it is estimated that they are destined to disappear due to the accumulation of sediments and organic matter (Thorp \& Covich, 2001; Lasso, Gutiérrez \& Morales, 2014). Despite most lakes being found in the northern hemisphere, there is a high diversity and variety of lake systems in South America, which are the result of the geomorphology and variety of climates present in the region (Aguilera et al., 2016; Likens, 2010; Benito et al., 2018).

Llames and Zagarese (2009) classified South American tropical lakes according to geomorphology and climatic characteristics. The present study was undertaken in two types of shallow $(<2.5 \mathrm{~m})$ : tropical mountain lakes and tropical lowland lakes. Tropical mountain lakes are characterized by being found at heights above $3500-4000$ m.a.s.1.; they are oligotrophic lake environments with low ionic concentrations, low temperature, and high transparency; they are categorized as cold polymictic (Florez \& Rios, 1998; Gutiérrez, 
Morales \& Lasso, 2014; Catalan \& Donato, 2016). The chemical conditions of these lakes vary according to their geomorphological origin (Vila \& Mühlhauser, 1987; Kappelle \& Horn, 2016). Tropical lowland lakes are characterized by being found between 0 and 1000 m.a.s.l.; they are meso- to eutrophic environments; they present high temperatures and are categorized as warm polymictic, with high concentrations of humic substances and organic matter (Hutchinson \& Löffler, 1956; Ramírez \& Viña, 1998; Wilhelm \& Adrian, 2008; Montoya \& Aguirre, 2009).

The aquatic communities present in lakes respond to constant changes in physical and chemical variables (Webb et al., 2002; Li et al., 2019). However, the plankton community responds more quickly than others to these changes and has a direct effect on the productivity of lentic environments because it supports to a large extent the trophic web, affecting the ecosystem structure and functioning (Anderson et al., 2002; Woodward et al., 2010). Phytoplankton is the main energy receptor in aquatic ecosystems; its composition and dynamics in the water column are regulated mainly by the incidence of light, temperature, nutrient availability, competition, hydraulic dynamics, and pression from herbivory (Reynolds, 1984, 2008; Kruk et al., 2011; Esteves \& Suzuki, 2011; Muñoz-López et al., 2017). Zooplankton not only regulates primary productivity, can also indicate the environmental state of aquatic systems over a given time period, due to the changes in the community in terms of diversity and abundance (Phan et al., 2015). Zooplankton also plays a fundamental role in the cycle of biogeochemical elements (Allen et al., 2005), increasing $\mathrm{CO}_{2}$ inputs through grazing, and mediating effects on primary productivity (Urabe et al., 2003; Li et al., 2019).

Since tropical mountain and lowland lakes can have different water physicochemical characteristics as well as different plankton communities inhabiting them, it is important to characterize and compare the organisms found in these environments (Barón et al., 2002; Gunkel, 2003; López-Martínez et al., 2017).
The present study adds new records of previously described species and to contribute to the knowledge of the planktonic communities present in tropical mountain and lowland lakes of the northeast Colombian Andes.

Some authors proposed that the difference between the community composition in tropical mountain lakes and lowland lakes is due to the biogeographic barrier of the Andes mountains (Wets, 1914; Coesel, 1992). Morever, from the high mountains to lowlands, a diversity of conditions associated with continuum of ecosystems impose a variety of dispersal pathways in aquatic organisms (Moritz et al., 2013). We hypothesized that regional and local variables influence the plankton richness and occurrence of species in the tropical lakes from the Northeast Colombian Andes. We predicted that species richness of the tropical lowland lakes is greater than tropical mountain lakes.

\section{MATERIALS AND METHODS}

Study area: Samples were collected at nine tropical lakes located in the northeastern part of Colombia in the Department of Santander (Fig. 1). The studied systems belong to two types of tropical lakes (mountain and lowland). Five tropical mountain lakes, located within the jurisdiction of the Páramo del Almorzadero, and four tropical lowland lakes located in the middle valley of the Magdalena River Basin were sampled (Junk, 1993; García \& Dister, 1990; Morales-Rivas et al., 2007).

The Páramo del Almorzadero belongs to the biome known as Paramo. It belongs to a Tropical Montane Grasslands and Shrublands system; the rain and evaporation pattern is monomodal and reaches $1379 \mathrm{~mm}$ in annual precipitation (Holdridge, 2000; Rivera, 2001; Olson et al., 2001, Hoekstra et al., 2005). The depth of mountain lakes is determined by the topography of the terrain and the retention capacity created by the moss mats and plants found in the system (Buytaert et al., 2006; Morales-Rivas et al., 2007; Aguilera, Lazzaro \& Coronel, 2013). 


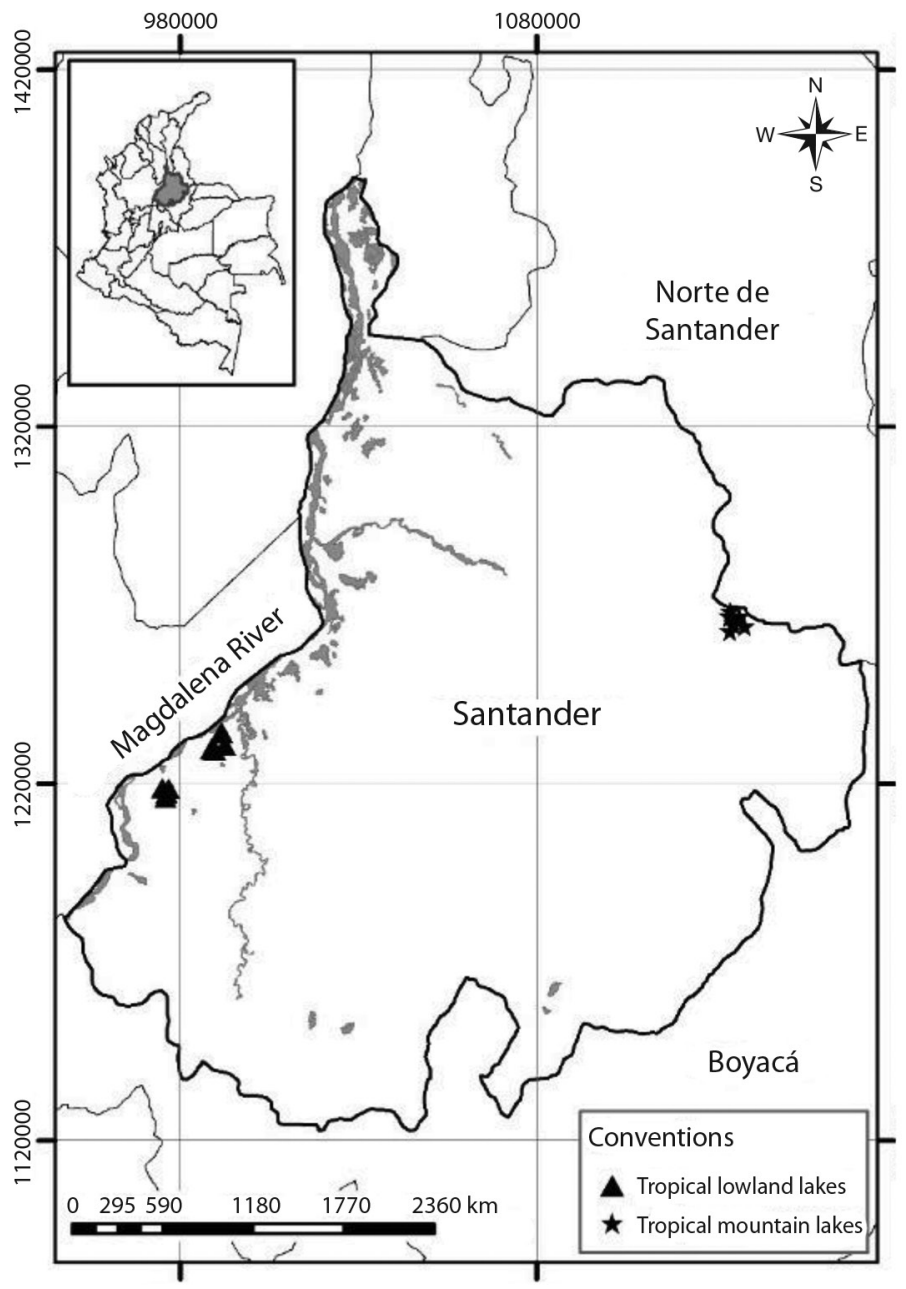

Fig. 1. Map and location of the study area, showing the nine tropical lakes of sampling.

The middle valley of the Magdalena River Basin is surrounded by tropical dry forest and wet tropical forest. It has bimodal precipitation and reaches $3000 \mathrm{~mm}$ in annual precipitation (García \& Dister, 1990; Holdridge, 2000; Gutiérrez et al., 2014). The depth of lowland tropical inland lakes is modulated by precipitation patterns (Arias, 1985; Montoya \& Aguirre, 2010; Montoya \& Aguirre, 2013; Ricaurte et al., 2019).

Sampling and data collection: A total of 27 plankton samples were collected in nine tropical lakes during July and August 2018. In each lake, three samples were collected. The following physical variables were measured in situ at each station: temperature $\left({ }^{\circ} \mathrm{C}\right)$, dissolved oxygen $(\mathrm{mg} / \mathrm{L}), \mathrm{pH}$, and electrical conductivity $(\mu \mathrm{S} / \mathrm{cm})$, using a Hach multiparameter probe (Conductivity: $0.5 \mu \mathrm{S} / \mathrm{cm}$, temperature: $\pm 0.3{ }^{\circ} \mathrm{C}$ and $\mathrm{mV}: 0.1 \mathrm{mV}$ ) and a Hanna probe (Dissolved oxygen: $\pm 1.5 \%$ F.S., $\pm 0.5^{\circ} \mathrm{C}$ ). Water transparency was measured with a Secchi disk (Tyler, 1968) and maximum depth was measured with a HONDEX ps-7 depth sounder. One liter of water-sample was taken at each station and filtered using Whatman GF/C filters $(0.7 \mu \mathrm{m})$ to estimate chlorophyll- $a$ concentration ex situ by 
centrifugation and measuring absorbance with a spectrophotometer (Shimadzu UV-Vis 1700 Series), following APHA Standard Methods 10200H (2005).

Phytoplankton samples were collected with horizontal tows using a standard $23 \mu \mathrm{m}$ net. Samples were fixed and preserved in buffered $4 \%$ formaldehyde and Lugol, using $0.5 \mathrm{ml}$ for $100 \mathrm{ml}$ of sample (APHA, 2005).

Zooplankton samples were collected with horizontal tows using a standard $63 \mu \mathrm{m}$ net and straining $80 \mathrm{~L}$ of water with a $41 \mu \mathrm{m}$ net. Samples were fixed and preserved in buffered $4 \%$ formaldehyde (APHA, 2005).

\section{Laboratory and stadistical analyses:} Organisms were identified using an optical Zeiss microscope with an AxioCam camera. Images of the species were obtained using the software Zen Blue 2.5 lite (Carl Zeiss Microscopy $\mathrm{GmbH}$ ). Identification was performed to the lowest possible taxonomic level using taxonomic guides by Huber-Pestalozzi (1955), Patrick \& Reimer (1966), Komárek (1974), Ruttner-Kolisko (1974), Koste (1978), Barber \& Haworth (1981), Sendacz \& Kubo (1982), Parra et al., (1982a, 1982b, 1982c, 1983a, 1983b), Ettl (1983), Komárek (1983), Komárek \& Foot (1983), Starmach (1983), Kudo (1985), Reid (1985), Tell (1986), Koste \& Shield (1987), Shield \& Koste (1992, 1993), Nogrady et al., (1993), Nogrady et al., (1995), Segers (1995), Alonso (1996), Cox (1996), Comas (1996), Suárez et al., (1996), ElmoorLoureiro (1997), Komárek \& Anagnostidis (1999), Gaviria (2000), Nogrady \& Segers (2002), Fernando (2002), Komárek \& Anagnostidis (2005), Elías et al., (2008), Haney (2013), González \& Inostroza (2017) and Siemensma (2019).

One percent of phytoplankton was identified to variety level; $11.3 \%$ of specimens were identified to species level and $87.3 \%$ of specimens were identified to genus level. A total of $70.7 \%$ of zooplankton was identified to species level and $29.3 \%$ was identified to genus level.

Analyzed specimens were deposited at the Natural History Museum of the Universidad
Industrial de Santander, in the Hydrobiological collection. Biological records were structured following the Darwin Core standard (DwC) and uploaded through the Integrated Publishing Tool of the Colombian node of the Global Biodiversity Information Facility (GBIF), SiB Colombia (Colombia Biodiversity Information) (2019).

We used the taxonomic classification system of Guiry y Guiry (2019), WoRMS Editorial Board (2019) and Siemensma (2019). These primary occurrence localities were obtained by searching in two electronic sources GBIF (2019) and SiB Colombia (2019), and bibliographic references.

Analysis of variance (ANOVA) was used to compare physical and chemical variables among tropical mountain lakes and tropical lowland lakes. Analysis of variance performed using the PAST software 4.02 (Hammer et al., 2009). Spatial relationships between the species found were established with a Jaccard similarity analysis (presence-absence) of identified organisms in the nine tropical lakes. The Jaccard similarity matrix was checked for significant pruning of groups (group average method) via the SIMPROF routine (999 simulations; $p=0.05$ ). Analysis of similarity (ANOSIM) was used to test if significant differences between the groups derived from the cluster analysis. Community analyses were performed with the statistical package Primer V7 (Clarke \& Gorley, 2006).

\section{RESULTS}

Physical and chemical variables: The nine studied lakes were located at between 92 and 3976 m.a.s.l. (Table 1). The highest $\mathrm{pH}$ values were found in the tropical lowland lakes (mean $=6.5)$ and the lowest in the tropical mountain lakes $($ mean $=5.6)$. The greatest conductivity was found in the tropical lowland lakes $($ mean $=90.6 \mu \mathrm{S} / \mathrm{cm})$ and the lowest in the tropical mountain lakes (mean $=5.1$ $\mu \mathrm{S} / \mathrm{cm})$. Dissolved oxygen was higher in the tropical mountain lakes $($ mean $=8.5 \mathrm{mg} / \mathrm{L}$ ) and the lowest in the tropical lowland lakes 


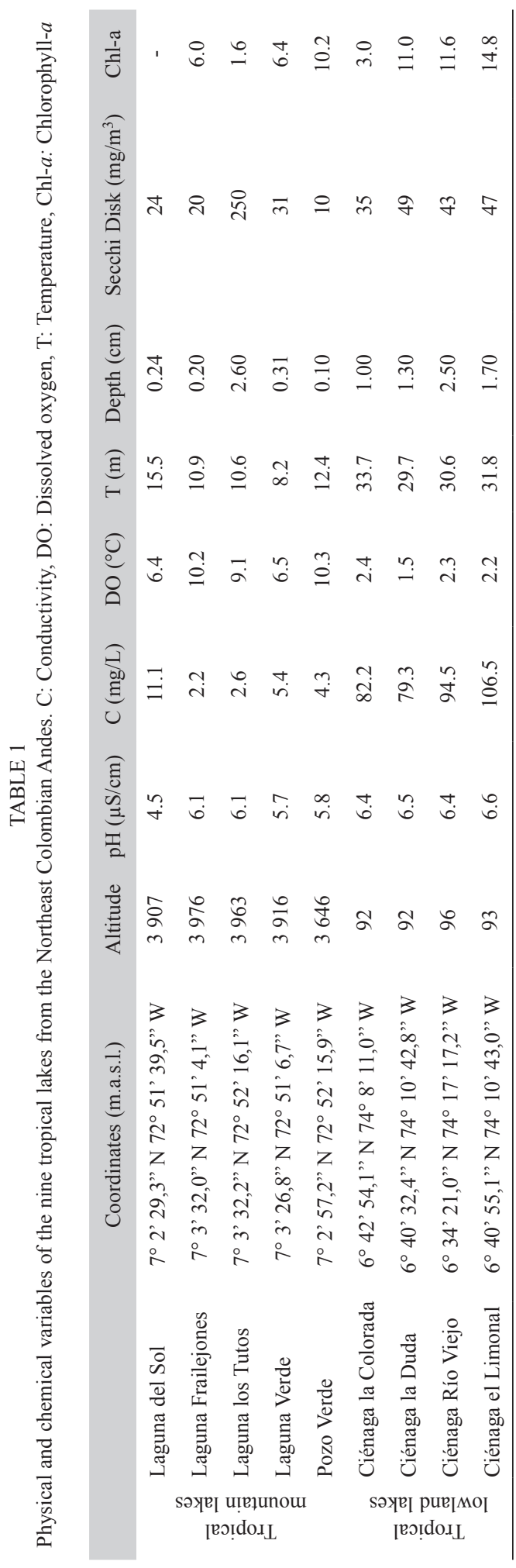

(mean $=2.1 \mathrm{mg} / \mathrm{L})$. The highest temperatures were observed in the tropical lowland lakes (mean $=31.5^{\circ} \mathrm{C}$ ) and the lowest in the tropical mountain lakes $\left(\right.$ mean $\left.=11.5{ }^{\circ} \mathrm{C}\right)$. The maximum depth was found in the tropical lowland lakes $($ mean $=1.6 \mathrm{~m})$ and the lowest in the tropical mountain lakes $($ mean $=0.8 \mathrm{~m}$ ). The highest transparency values were observed in the tropical mountain lakes (mean $=67 \mathrm{~cm}$ Secchi disk) and the lowest in the tropical lowland lakes $($ mean $=43.5 \mathrm{~cm}$ Secchi disk). The highest chlorophyll- $a$ concentrations were found in in the tropical lowland lakes (10.1 \pm $4.34 \mathrm{mg} / \mathrm{m}^{3}$; mean $\pm \mathrm{SE}$ ) and the lowest in the tropical mountain lakes $\left(6.1 \pm 3.04 \mathrm{mg} / \mathrm{m}^{3}\right.$; mean $\pm \mathrm{SE})$. ANOVA showed significant differences in $\mathrm{pH}(\mathrm{F}=23.4, \mathrm{p}=0.003)$, conductivity $(\mathrm{F}=192, \mathrm{p}<0.001)$, dissolved oxygen $(\mathrm{F}=58.2$, $\mathrm{p}=0.003)$ and temperature $(\mathrm{F}=291.3, \mathrm{p}<0.001)$ among tropical mountain lakes and tropical lowland lakes.

A total of 391 planktonic organisms were identified in the nine studied lakes within phytoplankton and zooplankton (Digital Appendix). Species richness among lakes ranged between 41-70 taxa, except Ciénaga Río Viejo which showed a between two and four times more diversity. Tropical lowland lakes showed $17.6 \%$ higher richness than tropical mountain lakes.

Phytoplankton: A total of 299 phytoplankton species were identified in the nine studied lakes (Fig. 2); these species were distributed in seven phyla, 13 classes, 31 orders, 57 families, and 96 genera. The phylum with greatest number of species was Charophyta (70), followed by Bacillariphyta (58), and Chlorophyta (58) (Digital Appendix).

A total of 120 phytoplankton species were identified in the five tropical mountain lakes; these species were distributed in six phyla, ten classes, 26 orders, 40 families, and 64 genera. The phylum with greatest number of species was Charophyta (49 species), followed by Bacillariophyta (23 species), Cyanobacteria (20 species), Chlorophyta (19 species), Ochrophyta 


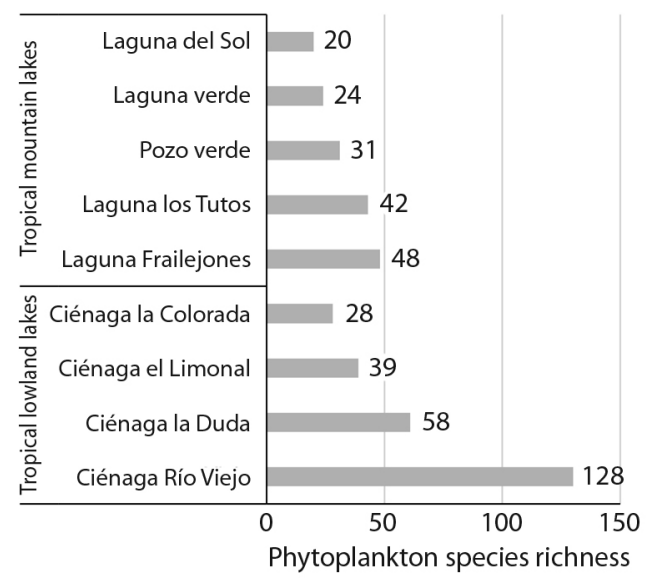

Fig. 2. Phytoplankton species richness of the nine tropical lakes from the Northeast Colombian Andes.
(5 species), and Miozoa (4 species) (Digital Appendix).

A total of 186 phytoplankton species were identified in the four tropical lowland lakes; these species were distributed in six phyla, 13 classes, 26 orders, 45 families, and 67 genera. Among the species found, four were identified to variety level (Aulacoseira granulata var. angustissima, Trachelomonas armata var. armata, Trachelomonas armata var. litoralensis, and Trachelomonas similis var. spinosa) (Fig. 3). The phylum with greatest number of species was Euglenozoa (47 species), followed by Bacillariophyta (39 species), Chlorophyta (39 species), Charophyta (21 species), Cyanobacteria (19 species), Ochrophyta (17 species) and Miozoa (4 species) (Digital Appendix).
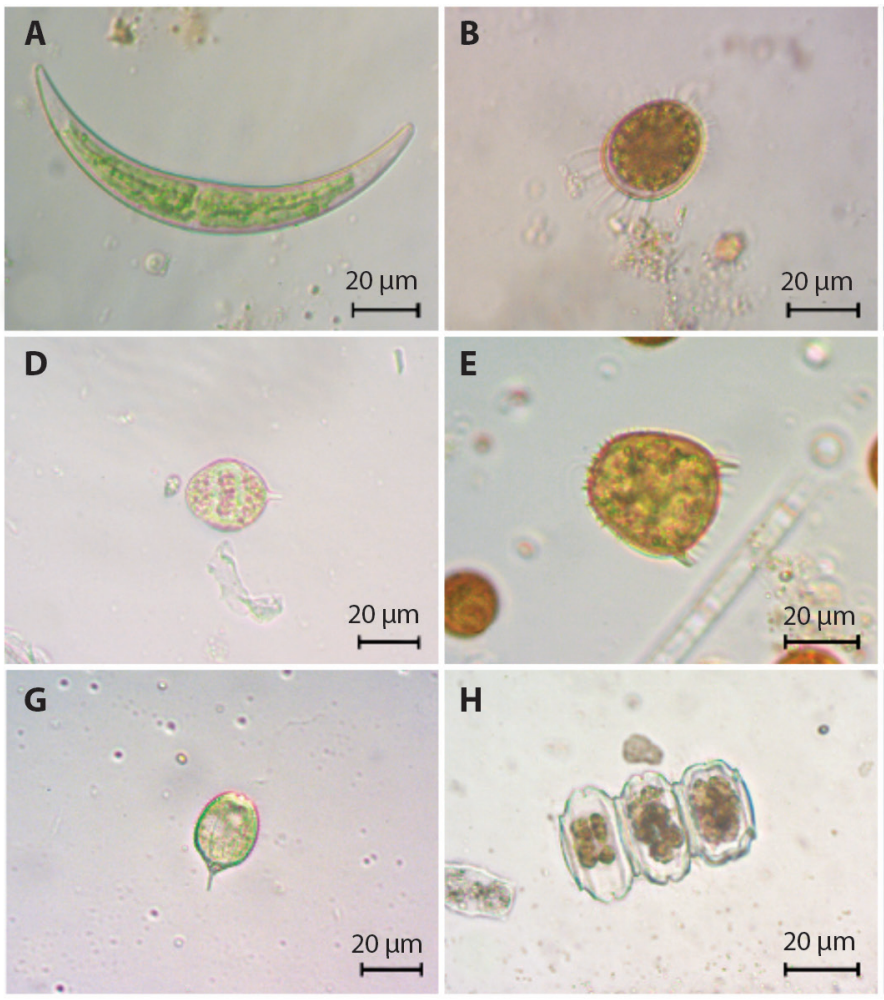

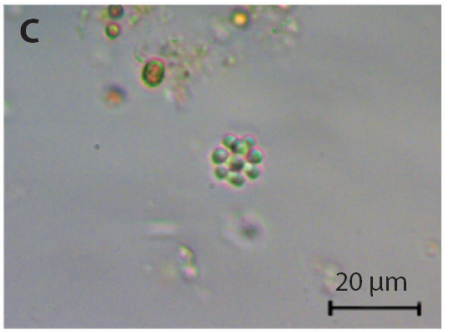

$\mathbf{F}$

$20 \mu \mathrm{m}$

I

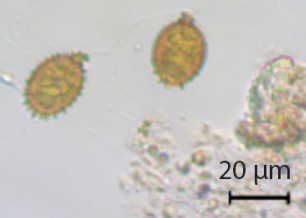

Fig. 3. Phytoplankton species of the nine tropical lakes from the Northeast Colombian Andes. a. Closterium venus, b. Trachelomonas armata var. armata, c. Coelastrum microporum, d. Lepocinclis ovum, e. Trachelomonas armata var. litoralensis, f. Eudorina elegans, g. Phacus suecicus, h. Desmidium sp3, i. Trachelomonas similis var. spinosa. 
Of the phytoplankton identified in the tropical lakes in this study, $37.1 \%$ of species were unique to tropical mountain lakes, 60.6 $\%$ were unique to tropical lowland lakes, and the remaining $2.3 \%$ corresponded to species shared between mountain and lowland tropical lakes (Digital Appendix). The seven phytoplankton species shared between tropical mountain lakes and tropical lowland lakes were Ankistrodesmus fusiformis, Eunotia sp6, Eunotia sp7, Pinnularia cf. major, Pinnularia sp13, Planktolyngbya sp1, and Pseudanabaena sp2.

A total of 60 new phytoplankton species records for the Department of Santander; 19 corresponded to species identified in tropical mountain lakes and 35 corresponded to species identified in tropical lowland lakes (Fig. 4). 15 new records were identified for Colombia (Digital Appendix).
Zooplankton: A total of 92 zooplankton species were identified in the nine studied lakes (Fig. 5); these species were distributed in four phyla, six classes, eight orders, 27 families, and 40 genera. The phyla with greatest number of species were Rotifera (58 species), Arthropoda (20 species), and Amoebozoa (12 species) (Digital Appendix).

A total of 53 zooplankton species were identified in the five tropical mountain lakes; these species were distributed in four phyla, five classes, five orders, 18 families, and 27 genera. The phylum with greatest number of species was Rotifera (58 species), followed by Arthropoda (18 species), Amoebozoa (12 species), and Cercozoa (4 species) (Supporting Information).

A total of 47 zooplankton species were identified in the four tropical lowland lakes;

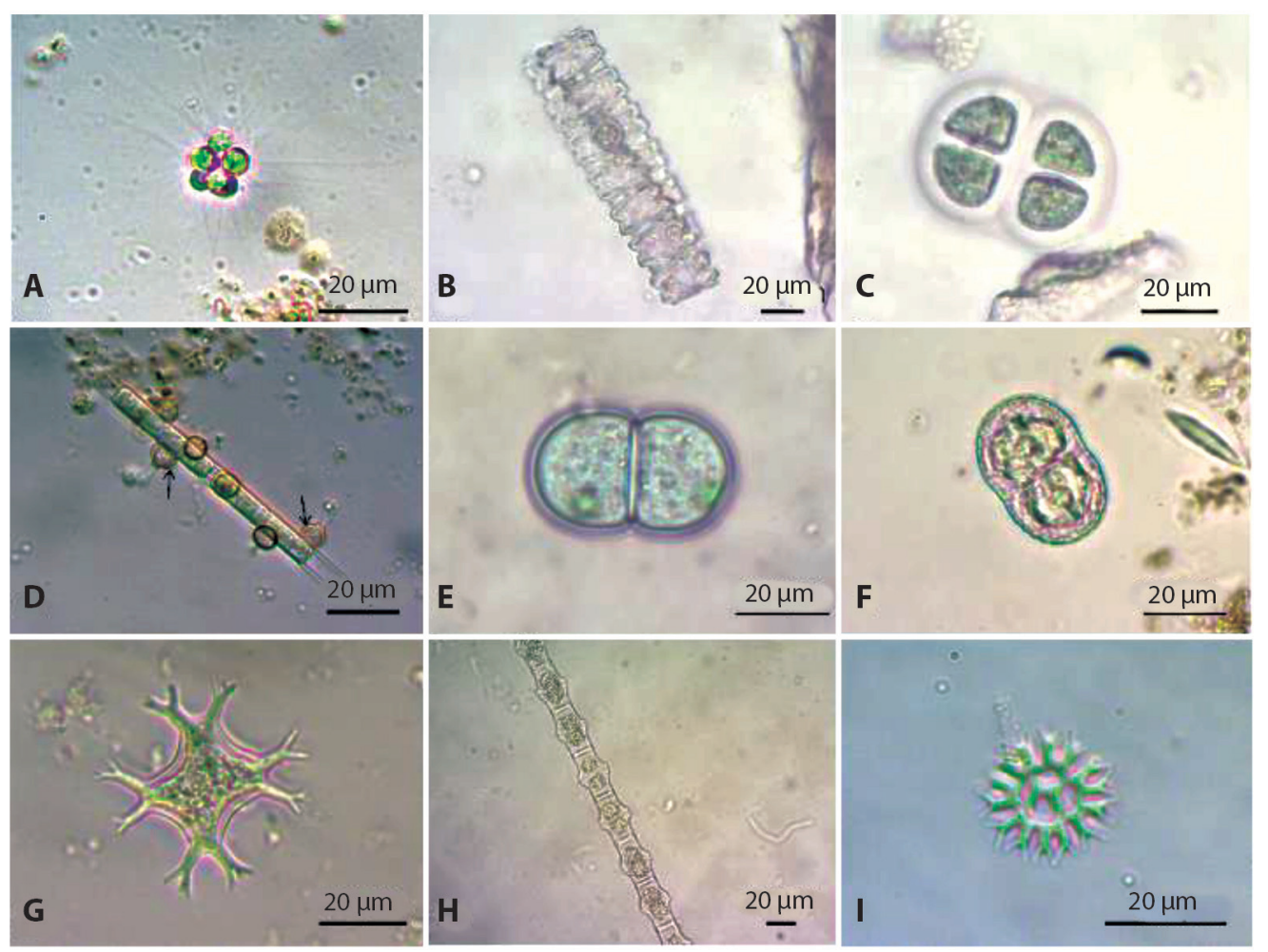

Fig. 4. Phytoplankton species of the nine tropical lakes from the Northeast Colombian Andes. a. Micractinium pusillum, b. Desmidium swartzii, c. Chroococcus turgidus, d. Lagynion sp1, e. Cyanothece aeruginosa, f. Actinotaenium cucurbita, g. Isthmochloron lobulatum, h. Bambusina brebissonii, i. Parapediastrum biradiatum. 


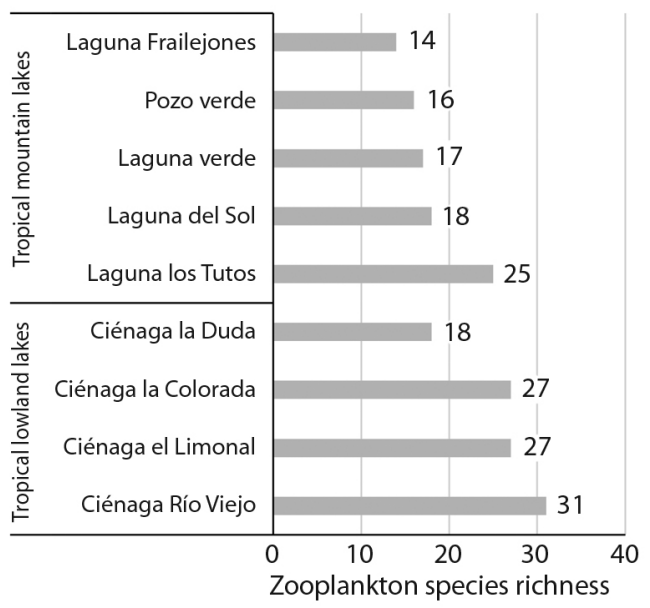

Fig. 5. Zooplankton species richness of the nine tropical lakes from the Northeast Colombian Andes. these species were distributed in four phyla, six classes, eight orders, 21 families, and 24 genera. The phylum with greatest number of species in these lakes was Rotifera (32 species), followed by Arthropoda (9 species), Amoebozoa (5 species), and Cercozoa (1 species) (Supporting Information).

Of the zooplankton identified in tropical lakes, $47.9 \%$ of species were unique to tropical mountain lakes, $41.7 \%$ were unique to tropical lowland lakes, and the remaining $10.4 \%$ were shared between tropical mountain and lowland lakes (Digital Appendix). The ten species shared between tropical mountain and lowland lakes were Arcella conica, Arcella sp1, Ascomorpha ecaudis, Asplanchna seiboldii, Brachionus falcatus, Calanoida sp1, Centropyxis sp1, Lecane bulla, and Trichocerca similis (Fig. 6). A total of 41 new records of

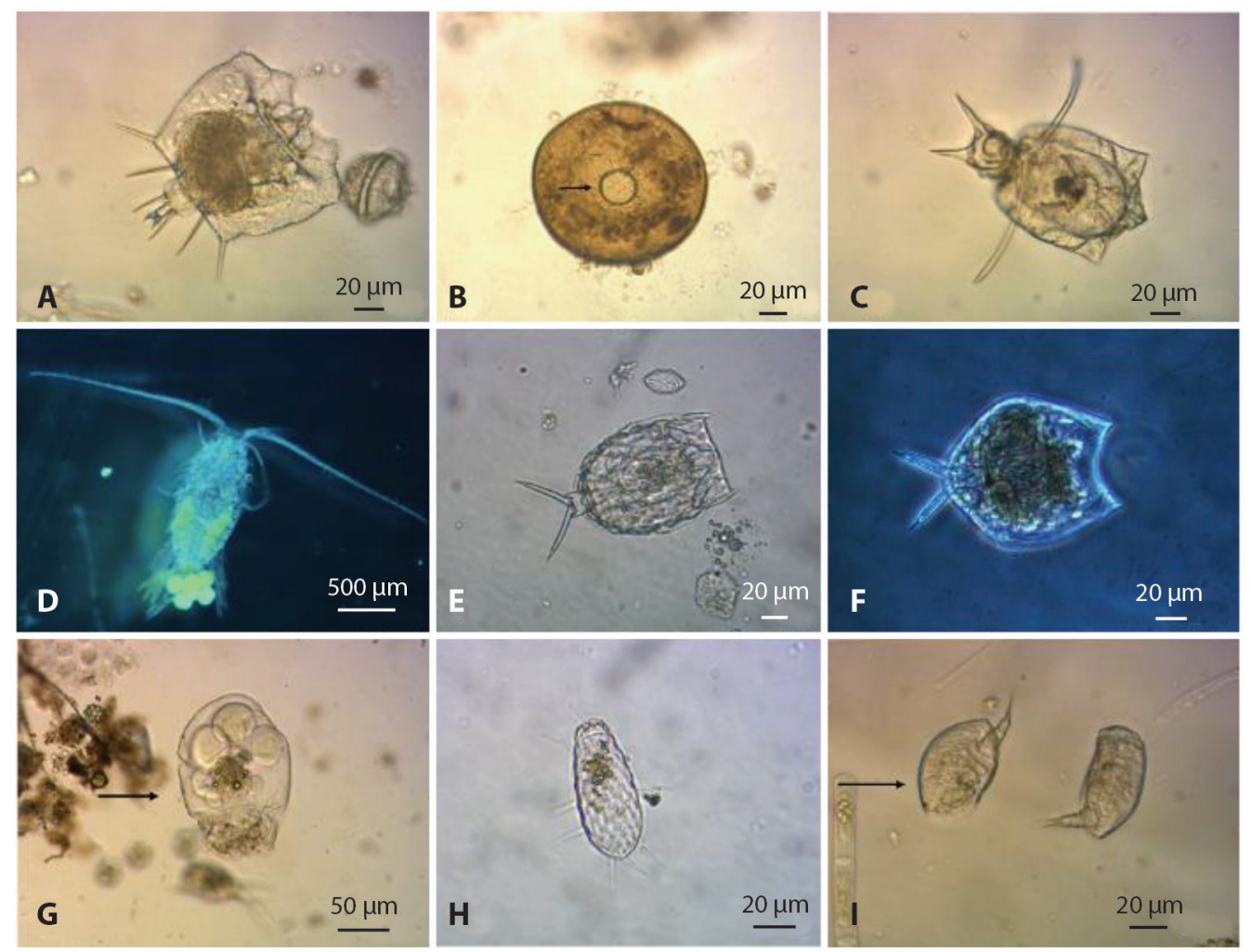

Fig. 6. Zooplankton species of the nine tropical lakes from the Northeast Colombian Andes. a. Macrochaetus sericus, b. Arcella catinus, c. Trichotria pocillum, d. Boeckella gracilis, e. Lecane sp3, f. Lecane luna, g. Asplachna sieboldii, h. Euglypha acanthophora, i. Colurella obtuse. 


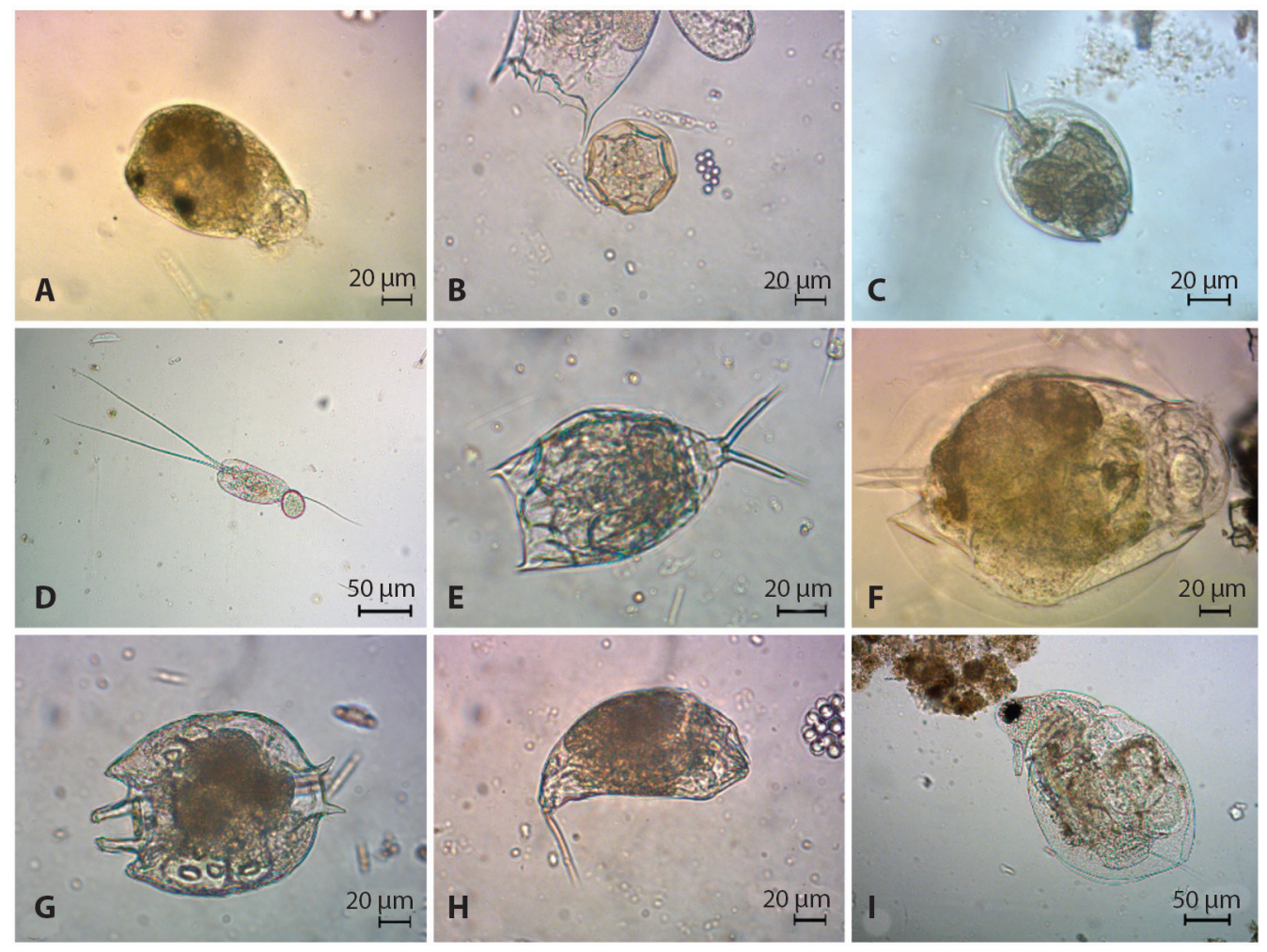

Fig. 7. Zooplankton species of the nine tropical lakes from the Northeast Colombian Andes. a. Ascomorpha ecaudis, b. Arcella conica, c. Lepadella patella, d. Filinia longiseta, e. Lecane eutarsa, f. Euchlanis dilatata, g. Platyas quadrcornis, h. Trichocerca stylata, i. Moina micrura.

zooplankton species were found for the Department of Santander; 12 corresponded to species identified in tropical mountain lakes and 22 corresponded to species identified in tropical lowland lakes (Fig. 7).

A total of 27 plankton samples were entered into the Hydrobiological collection of the Natural History Museum UIS. The entered records correspond to UIS-MHB-2299, UISMHB-2302, UIS-MHB-2704, UIS-MHB-2166, UIS-MHB-2187, UIS-MHB-2194, UISMHB-2195, UIS-MHB-2198, UIS-MHB-2199, UIS-MHB-2201， UIS-MHB-2206， UISMHB-2209, UIS-MHB-2223, UIS-MHB-2240, UIS-MHB-2243, UIS-MHB-2251, UISMHB-2254, UIS-MHB-2255, UIS-MHB-2257, UIS-MHB-2280, UIS-MHB-2281， UISMHB-2287, UIS-MHB-2291, UIS-MHB-2292, UIS-MHB-2296, UIS-MHB-2299, UISMHB-2302 y UIS-MHB-2704. The complete list of species is available http://datos.biodiversidad.co

The Jaccard similarity analysis showed differences in the plankton communities found in the tropical mountain and lowland lakes; the cophenetic correlation was 0.87 . The five tropical mountain lakes were grouped in the analysis; within this group there was similarity between Laguna del Sol and Laguna Los Tutos, and between Laguna Frailejones and Pozo Verde, whereas Laguna Verde was the least similar. The four tropical lowland lakes were grouped; within this group there was similarity among Ciénaga La Colorada, Ciénaga El Limonal, and Ciénaga Río Viejo, whereas the least similar lake in this group was Ciénaga $\mathrm{La}$ Duda (Fig. 8). ANOSIM showed significant differences between the groups derived from the cluster analysis $($ Global $\mathrm{R}=0.89, \mathrm{p}=0.001)$. 


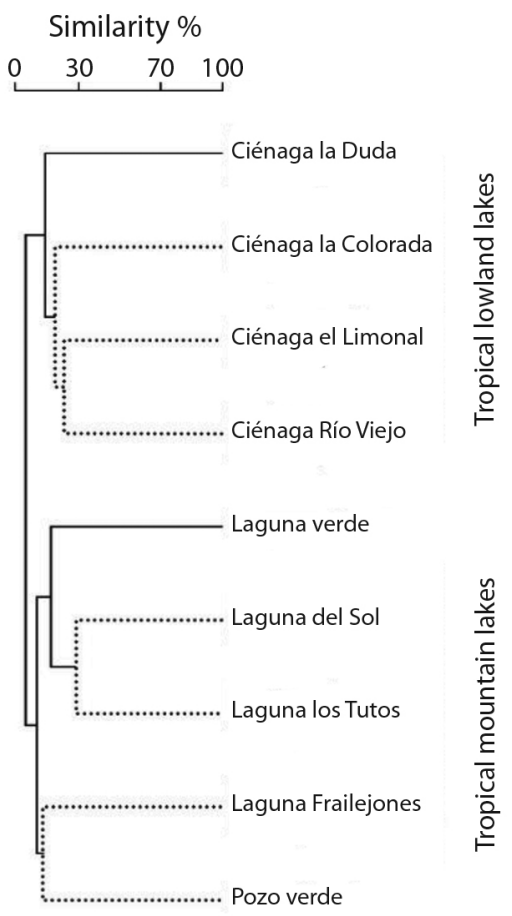

Fig. 8. Dendrogram of cluster analysis using the Jaccard similarity index of planktonic species. Dotted lines: significant differences (SIMPROF, $\mathrm{p}<0.05$ ).

\section{DISCUSSION}

The present study contributes to a better limnological understanding of mountain and lowland tropical lakes located in the northeast Colombian Andes. We present the data corresponding to six physicochemical variables and a list of 391 plankton species, and expand the available information on the planktonic organisms of tropical lakes. Fifteen taxa of planktonic organisms are recorded for the first time in the mountainous and lowland areas of the Northeast Colombian Andes.

Physical and chemical variables: The physicochemical variables of the five tropical mountain lakes studied here presented similar characteristics to those reported by ZapataAnzola et al., (2006) and Roldán \& Ramírez (2008). The low conductivity and $\mathrm{pH}$ values tending towards acidity observed in this study were probably due to geomorphology and basin substrate, because the lakes located in the northeast Colombian Andes are of glacial origin and present crystalline rocks of slow chemical weathering (Flórez, 2003; Buytaert et al. 2006; Bare \& Ashton, 2015; Borsdorf \& Stadel, 2015; Catalan \& Donato, 2016). The high dissolved oxygen levels reported for these tropical lakes are probably due to location, as they are found in areas of great wind exposure (Donato 1991; Rivera-R et al., 2005; Hernández-Atilano et al., 2012; Herrera-Martínez et al., 2017).

The $\mathrm{pH}$ and conductivity values recorded for the tropical lowland lakes in the study area were similar to those reported for other lowland lakes of the Middle Magdalena River, such as Ciénaga de Paredes, Ciénaga de Chucuri, Ciénaga de Aguas Negras, Ciénaga San Silvestre, Ciénaga del Opón, and Ciénaga Miramar (Pedraza et al., 1989; Ramírez \& Viña, 1998; Pava et al., 2006; Barón-Rodríguez et al., 2006, Roldán \& Ramírez, 2008; García \& Dister, 1990; Criales-Hernández \& Jerez-Guerrero, 2016; Solís-Parra \& Criales-Hernández, 2016). Conductivity values indicated high ionic and dissolved solids content, probably associated with river runoff and anthropogenic activities from agricultural and livestock farming activities in the area (Kalff, 2002; Peña et al., 2005; Gallo-Sánchez et al., 2009; Pinilla et al., 2010; Barón-Rodríguez et al., 2006; Montoya \& Aguirre, 2013; Silva et al., 2017).

Plankton analysis: The planktonic organisms identified in this study coincide with information recorded for other tropical mountain (Gaviria, 1989; Donato, 1991; Gaviria, 1993; Donato et al., 1996; Donato, 2010; Aranguren-Riaño et al., 2011; Muñoz-López et al., 2017) and lowland lakes (Duque \& Núñez-Avellaneda, 2000; Pinilla, 2005; BarónRodríguez et al., 2006; Sala et al., 2008; Álvarez, 2010; Jaramillo-Londoño \& Pinto-Coelho, 2010; Rivera et al., 2010; Andrade-Sossa et al., 2011; Jaramillo-Londoño \& Aguirre-Ramírez, 2012; Montoya-Moreno et al., 2012; AguirreRamírez, 2014; Sala et al., 2015) of Colombia. 
The greatest phytoplankton richness was found for the phyla Charophyta, Bacillariophyta, and Chlorophyta; this was possibly due to these species constituting the greatest percentage of species in lentic systems, despite differences in the environmental characteristics of mountain and lowland lakes (Donato et al., 1996; Canosa y Pinilla, 2007; Donato, 2010; Alba-M et al., 2011; Montoya-Moreno et al., 2013; Osorio-Ávila \& Manjarres-García, 2015).

The species richness of phytoplankton in this work is high as compared with the results of other studies in tropical lakes. For example, Castaño et al., (2010) observed 25 phytoplankton species in Laguna Negra, Muñoz-López et al., (2017) reported 49 phytoplankton taxa in Lago de Tota, Jaramillo-Londoño \& AguirreRamirez (2012) recorded 74 phytoplankton species in the Ciénaga de Ayapel, Pava et al., (2006) reported 58 in the Ciénaga de San Silvestre. However, Donato et al., (2010) found a higher species richness than our studie, they identified 142 phytoplankton species in 20 tropical mountain lakes distributed along the three Andean Cordilleras.

The richness of zooplankton species belonging to the Rotifera phylum was probably due to the amount of food available through detritus pathways and the availability of particulate organic matter, small algae, and decomposing organisms such as bacteria and fungi (Nogrady et al., 1993; Pinilla et al., 2007; Andrade-Sossa et al., 2011; Burian et al., 2016). All the tropical lakes studied in this work had associated aquatic vegetation. The high richness of microcrustaceans was probably due to the presence of macrophytes, which act as both shelter against predation and food source for cladocers and copepods (Cazzanelli et al., 2008; Villabona-González et al., 2011; Choedchim et al., 2017).

The proportion of planktonic species unique to tropical lowland lakes $(51.2 \%)$ and tropical mountain lakes (42.5\%), as well as the low similarity found in the Jaccard analysis, indicated high heterogeneity in the ecological conditions of the studied tropical lakes. The remaining $6.4 \%$ of specimens corresponded to
17 planktonic species shared between the two types of tropical lake. These shared species were found in lakes with high concentrations of organic matter (Donato, 1987; Tuchman 1996; Klug, 2002; Tuchman et al., 2006; AndradeSossa et al., 2011; Brighenti et al., 2018; Mello et al., 2018).

After reviewing databases of biological collections and published studies on plankton species present in tropical lakes of Colombia, the present study reported 15 new records for the country. This high number of new records of planktonic species is probably due to a lack of published descriptions. The present study fills a gap in the knowledge of planktonic communities of the tropical lakes from the Northeast Colombian Andes.

Ethical statement: authors declare that they all agree with this publication and made significant contributions; that there is no conflict of interest of any kind; and that we followed all pertinent ethical and legal procedures and requirements. All financial sources are fully and clearly stated in the acknowledgements section. A signed document has been filed in the journal archives.

\section{ACKNOWLEDGEMENTS}

This manuscript is a product of the project "Investigación de la biodiversidad y los servicios ecosistémicos para la gestión integral del territorio - descubriendo los ecosistemas estratégicos para el fortalecimiento de la gobernanza en el departamento de Santander (SantanderBIO)", financed by funds from Sistema General de Regalias de la República de Colombia. We want to thank to Gobernación de Santander for gesturing resources for this project and for their supervision and advise of administrative issues. We gratefully acknowledge the local community for their kindness during our expeditions. The authors acknowledge constructive comments received from anonymous referees and the associate editors, which improved the manuscript substantially. 


\section{RESUMEN}

Ampliación del conocimiento de la diversidad de plancton de los lagos tropicales de los Andes nororientales colombianos. Introducción: En los lagos tropicales, un gran número de comunidades planctónicas no han sido registradas aún, limitando el entendimiento de como estos ecosistemas funcionan, y el papel que estos organismos cumplen dentro de él. Objetivo: Contribuir al conocimiento de las comunidades planctónicas presentes en lagos tropicales ubicados en zonas altas y bajas de los Andes nororientales colombianos y reportar nuevos registros de especies previamente descritas. Métodos: Se recolectaron muestras planctónicas, se tomaron variables fisicoquímicas en nueve lagos tropicales, se identificaron los organismos y se realizó una revisión en portales de datos y artículos científicos con el fin de conocer cuales eran nuevos registros para Colombia. Resultados: Se presentan los datos correspondientes a seis variables fisicoquímicas para lagos tropicales de esta región y se amplía información que existe sobre organismos presentes en lagos tropicales mediante la elaboración una lista con 391 taxones (299 fitoplancton y 92 zooplancton). La proporción de taxones únicos identificados y la baja similitud encontrada en el análisis de Jaccard indican alta heterogeneidad de condiciones ecológicas en los nueve lagos tropicales estudiados. Conclusiones: La identificación de los 391 taxones y los 15 nuevos registros, contribuyen al listado de organismos planctónicos presentes en lagos tropicales, ubicados en zonas altas y bajas del noreste de los Andes colombianos.

Palabras clave: Plancton; ecosistemas acuáticos; tierras bajas; alta montaña; riqueza; Colombia.

\section{REFERENCIAS}

Aguilera, X., Declerck, S., De Meester, L., Maldonado, M., \& Ollevier, F. (2006). Tropical high Andes lakes: A limnological survey and an assessment of exotic rainbow trout (Oncorhynchus mykiss). Limnologica, 36(4), 258-268.

Aguilera, X., Lazzaro, X., \& Coronel, J. S. (2013). Tropical high-altitude Andean lakes located above the tree line attenuate UV-A radiation more strongly than typical temperate alpine lakes. Photochemical \& Photobiological Sciences, 12, 1649. https://doi.org/10.1039/ c3pp $25285 \mathrm{j}$

Aguirre-Ramírez, N. J. (2014). El plancton de la Ciénaga de Cachimberos, municipio de Cimitarra Santander, Colombia. Revista Científica en Ciencias Ambientales y Sostenibilidad, 1(1), 29-49.

Alba-M, A., D. M. Jiménez, W. López y S. Duque. 2011. Revisión de los estudios de las algas planctónicas de la laguna de Fúquene (Boyacá, Colombia). Iheringia 66 (1): 147- 156.
Allen, A. P., Gillooly, J. F., \& Brown, J. H. (2005). Linking the global carbon cycle to individual metabolism. Functional Ecology, 19(2), 202-213.

Alonso, M. (1996) Crustacea, Branchiopoda Fauna Iberica. Vol. 7. Museo Nacional de Ciencias Naturales, CSIC, Madrid, pp. 1-486.

Álvarez, J. P. (2010). Caracterización limnológica de las ciénagas de Arcial, El Porro y Cintura (río San Jorge) y Bañó, Charco Pescao y Pantano Bonito (río Sinú), departamento de Córdoba. Colombia diversidad biótica IX: Ciénagas de Córdoba: Biodiversidad-ecología y manejo ambiental, 201(0), 509-558.

Anderson, D. M., Glibert, P. M., \& Burkholder, J. M. (2002). Harmful algal blooms and eutrophication: nutrient sources, composition, and consequences. Estuaries, 25(4), 704-726.

Andrade-Sossa, C., García-Folleco M., Rodríguez-Munar C., Duque S., \& Realpe E. (2011). Efectos de la fluctuación del nivel del agua sobre la estructura del ensamblaje de rotíferos en el lago Largo (Sistema Yahuarcaca-llanura de inundación del río Amazonas-Colombia). Caldasia, 33(2).

APHA - American Public Health Association (2005). Standard methods for the examination of water and wastewater, 21th ed. Washington: APHA.

Aranguren-Riaño, N., Guisande, C., \& Ospina, R. (2011). Factors controlling crustacean zooplankton species richness in Neotropical lakes. Journal of Plankton Research, 33(8), 1295-1303.

Arias, P. (1985). Las ciénagas en Colombia. Revista Divulgación Pesquera Inderena, 22, 39-70.

Barber, H. G., \& Haworth, E. Y. (1981). A guide to the morphology of the diatom frustule: with a key to the British freshwater genera. Freshwater Biological Association.

Bare, M. C., \& Ashton, M. S. (2015). Growth of native tree species planted in montane reforestation projects in the Colombian and Ecuadorian Andes differs among site and species. New forests, 47(3), 333-355.

Barón, J. S., Poff, N. L., Angermeier, P. L., Dahm, C. N., Gleick, P. H., Hairston Jr, N. G., ... \& Steinman, A. D. (2002). Meeting ecological and societal needs for freshwater. Ecological Applications, 12(5), $1247-1260$

Barón-Rodríguez, M. M., Gavilán-Díaz, R. A., \& Ramírez, J. J. (2006). Variabilidad espacial y temporal en la comunidad de cladóceros de la Ciénaga de Paredes (Santander, Colombia) a lo largo de un ciclo anual. Limnetica, 25(3), 623-636.

Benito X, Fritz SC, Steinitz-Kannan M, Tapia PM, Kelly MA, Lowell TV (2018) Geo-climatic factors drive diatom community distribution in tropical 
South American freshwaters. Journal of Ecology 106(4):1660-1672. https://doi.org/10.5061/dryad. $\mathrm{ck} 7 \mathrm{pt}$

Borsdorf, A., \& Stadel, C. (2015). Factors, Processes and Spaces of Physical Geography. In The Andes (pp. 31-75). Springer, Cham.

Brighenti, L. S., Staehr, P. A., M. Brandão, L. P., Barbosa, F. A., \& Bezerra-Neto, J. F. (2018). Importance of nutrients, organic matter and light availability on epilimnetic metabolic rates in a mesotrophic tropical lake. Freshwater Biology, 63(9), 1143-1160.

Burian, A., Schagerl, M., Yasindi, A., Singer, G., Kaggwa, M. N., \& Winder, M. (2016). Benthic-pelagic coupling drives non-seasonal zooplankton blooms and restructures energy flows in shallow tropical lakes. Limnology and Oceanography, 61(3), 795-805.

Buytaert, W., Célleri, R., De Bièvre, B., Cisneros, F., Wyseure, G., Deckers, J., \& Hofstede, R. (2006). Human impact on the hydrology of the Andean páramos. Earth-Science Reviews, 79(1-2), 53-72.

Cardozo, A., Bermúdez, A., Aranguren-Riaño, N., \& Duque, S. R. (2005). Algas planctónicas del lago de Tota: listado taxonómico actualizado. Ciencia en desarrollo, 2(1), 80-88.

Castaño, D. R. T., Salazar, M. T. J., Serna, D. M. O., Correa, R. M., \& Salgado, P. A. (2010). Estudio limnológico de la Laguna Negra. Zona amortiguadora del PNN Los Nevados. Boletín científico, Centro de museos: Museo de historia humana, 23-38.

Catalan, J., \& Donato, J. C. (2016). Perspectives for an integrated understanding of tropical and temperate high-mountain lakes. Journal of Limnology, 75, 215-234

Cazzanelli, M., Warming, T. P., \& Christoffersen, K. S. (2008). Emergent and floating-leaved macrophytes as refuge for zooplankton in a eutrophic temperate lake without submerged vegetation. Hydrobiologia, 605(1), 113-122.

Choedchim, W., Van Damme, K., \& Maiphae, S. (2017). Spatial and temporal variation of Cladocera in a tropical shallow lake. In Annales de LimnologieInternational Journal of Limnology (Vol. 53, pp. 233252). EDP Sciences.

Clarke, K. R., \& Gorley, R. N. (2006). Primer v6: User Manual and Tutorial. Primer-E Ltd, Plymouth.

Coesel, P.F.M. (1992). Desmid assemblies along altitude gradients in Colombia. Nova Hedwigia, 55(3-4), 353-366.

Comas, A. (1996). Las Chlorococcales dulceacuícolas de Cuba.[The freshwater Chlorococcids of Cuba.] Stuttgart: J. Cramer. 192p., il. Bibliotheca Phycologica.
Cox, E. J. (1996). Identification of freshwater diatoms from live material. Chapman and Hall. London, UK, 158.

Criales-Hernández, M. I., \& Jerez-Guerrero, M. (2016). First record of Utricularia foliosa L. (Lentibulariaceae) and its food spectrum from the Ciénaga de Paredes, Santander, Colombia. Actualidades Biológicas, 38(104), 45-51.

DoNascimiento, C., Herrera-Collazos, E. E., Herrera-R, G. A., Ortega-Lara, A., Villa-Navarro, F. A., Oviedo, J. S. U., \& Maldonado-Ocampo, J. A. (2017). Checklist of the freshwater fishes of Colombia: a Darwin Core alternative to the updating problem. ZooKeys, (708), 25

Donato, J., Duque, S., Mora, E., \& Osejo, L. (1987). Estructura y dinámica del fitoplancton de la Laguna de Fúquene (Cundinamarca, Colombia). Revista de la Academia Colombiana de Ciencias Exactas y Naturales, 16(62), 113-144.

Donato R, J. C. (1991). Fitoplancton y aspectos físicos y químicos de la laguna de Chingaza en Cundinamarca, Colombia. Caldasia, 489-500.

Donato R, J., González, G., \& Rodríguez, M. (1996). Ecología de dos sistemas acuáticos de páramo. Academia Colombiana de Ciencias Exactas, Físicas y Naturales.

Donato-Rondón, J. (2010). Phytoplankton of Andean lakes in Northern Southamerica (Colombia). Composition and distribution factors.

Downing, J. A., Prairie, Y. T., Cole, J. J., Duarte, C. M., Tranvik, L. J., Striegl, R. G., ... \& Middelburg, J. J. (2006). The global abundance and size distribution of lakes, ponds, and impoundments. Limnology and Oceanography, 51(5), 2388-2397.

Duque, S. R., \& Núñez-Avellaneda, M. (2000). Microalgas acuáticas de la Amazonía colombiana. Biota Colombiana, 1(2).

Echenique, R., Núñez-Avellaneda, M., \& Duque, S.R. (2004). Chlorococcales de la Amazonia Colombiana I: Chlorellaceae y Scenedesmaceae. Caldasia 26 (1):37-51

Elías-Gutiérrez, M., E. Suárez, M. A. Gutiérrez, M. Silva, J. G. Granados Ramírez, \& T. Garfias. (2008). Cladócera y Copépoda de las aguas continentales de México. MÉXICO: Semarnat.

Elmoor-Loureiro, L.M. (1997). Manual de identificação de cladóceros límnicos do Brasil. Universa-UCB, Brasilia, Brasil.

Esteves, F. A., \& Suzuki, M. S. (2011). Comunidade Fitoplanctônica. In F. A. Esteves (Ed.), Fundamentos de Limnología $3^{\circ}$ edición (pp. 375-445). Rio de Janeiro: Editora Interciência. 
Ettl, H. (1983). Chlorophyta I. Phytomonadina. Subwasserflora Von Mitteleuropa, 9.

Fernando, C. H. (2002). Guide to tropical freshwater zooplankton: identification, ecology and impact on fisheries. In Guide to tropical freshwater zooplankton: identification, ecology and impact on fisheries. Backhuys.

Florez, A., \& Ríos, K. (1998). Las lagunas de alta montaña. Cuadernos de Geografia: Revista Colombiana de Geografia, 7(1-2), 25-49.

Flórez, A. (2003). Colombia: evolución de sus relieves y modelados. Univ. Nacional de Colombia.

Gallo-Sánchez, L., N. Aguirre-Ramírez, J. Palacio-Baena, \& J. Ramírez-Restrepo. (2009). Zooplancton (Rotífera y Microcrustacea) y su relación con los cambios del nivel del agua en la ciénaga de Ayapel, Córdoba, Colombia. Caldasia, 31(2): 339-353.

García, L. C., \& Dister, E. (1990). Operación El Dorado: Restauración y conservación de hábitats de la planicie de inundación del medio-bajo Magdalena. Interciencia, 15(6), 396-410

Gaviria, S. (1989). The calanoid fauna (Crustacea, Copepoda) of the Cordillera Oriental of the Colombian Andes. Hydrobiologia, 178(2), 113-134.

Gaviria, S. (1993). Crustacean plankton of a high altitude tropical lake: Laguna de Chingaza, Colombia. Internationale Vereinigung für theoretische und angewandte Limnologie: Verhandlungen, 25(2), 906-911.

Gaviria, S. (2000). Guía de laboratorio para identificación de Cladóceros, Copépodos y Rotíferos (Curso Sistemática del Zooplancton de las aguas continentales de Colombia). Colombia: Programa de Postgrado, Universidad de Antioquia, Medellín.

Gaviria, S., \& Aranguren, N. (2007). Especies de vida libre de la subclase Copepoda (Arthropoda, Crustacea) en aguas continentales de Colombia. Biota Colombiana, 8(1).

Gaviria, S., \& Aranguren-Riaño, N. (2019). Continental copepods (Crustacea: Hexanauplia) of Colombia: revision and additions to the inventory. Biota Colombiana, 20(1), 50-74.

Global Biodiversuty Information Facility - GBIF. (2019). Global biodiversity information facility web page: https://www.gbif.org. Accessed July 15, 2019.

González S. M., \& Inostroza, D. (2017). Manual taxonómico y fotográfico de géneros fitoplanctónicos (excl. Diatomeas) de 7 lagunas del Gran Concepción, Concepción, Chile. 172 págs.

Guiry, M.D., \& Guiry, G. M. (2019). AlgaeBase. Worldwide electronic publication, National University of
Ireland, Galway. http://www.algaebase.org; searched on 16 July 2019.

Gunkel, G. (2003). Limnología de un Lago Tropical de Alta Montaña, en Ecuador: Características de los sedimentos y tasa de sedimentación. En: Revista de Biología Tropical, 51(2), 381-392.

Gutiérrez, F. P., Morales-B., D. y Lasso, C. A. (2014). Humedales interiores de Colombia: principales investigaciones, tipologías y propuestas de clasificación. En Lasso, C. A., Gutiérrez, F. de P. y Morales-B, D. (Eds). X. Humedales interiores de Colombia: identificación, caracterización y establecimiento de límites según criterios biológicos y ecológicos. Serie Editorial Recursos Hidrobiológicos y Pesqueros Continentales de Colombia. Pp. 67-87. Bogotá, D.C.: Instituto de Investigación de Recursos Biológicos Alexander von Humboldt.

Hammer, O., Harper, D. A. T., \& Ryan, P. D. (2009). PAST: paleontological statistics software package for education and data analysis, Version 1.94 b. http. folk. uio. no/ohammer/past. Accessed, 9.

Haney, J. F., Aliberti, M. A., Allan, E., Allard, S., Bauer, D. J., Beagen, W., ... \& Dufresne, J. (2013). An-imagebased key to the zooplankton of North America. Version 5.0. University of New Hampshire Center for Freshwater Biology.

Hernández-Atilano, E., Palacio Baena, J. A., Aguirre Ramírez, N. J., Ramírez Restrepo, J. J., Guisande González, C., Duque, S. R., ... \& Mogollón, M. J. (2012). Rasgos morfológicos del fitoplancton en seis sistemas leníticos de las regiones Amazónica, Andina y Caribe de Colombia.

Herrera-Martínez, Y., Paggi, J. C., \& García, C. B. (2017). Cascading effect of exotic fish fry on plankton community in a tropical Andean high mountain lake: a mesocosm experiment. Journal of Limnology, 76(2).

Hoekstra, J. M., Boucher, T. M., Ricketts, T. H., \& Roberts, C. (2005). Confronting a biome crisis: global disparities of habitat loss and protection. Ecology Letters, 8(1), 23-29.

Holdridge, L. R. (2000). Ecología basada en zonas de vida. Agroamérica (No. 83).

Huber-Pestalozzi, G. (1955). Das Phytoplankton des Süsswassers. Systematik und biologie. 4. Teil. Euglenophyceen. In: Die Binnengewässer. Band 16, 4. Teil. (Thienemann, A. Eds). pp. [i]-ix, 1-606. Stuttgart: E.Schweizerbart'sche Verlagsbuchhandlung (Nägele u. Obermiller).

Hutchinson, G. E., \& Löffler, H. (1956). The thermal classification of lakes. Proceedings of the National Academy of Sciences of the United States of America, 42(2), 84 . 
Hutchinson, G. E. (Ed.) (1957). A Treatise on Limnology. Vol 1: Georgraphy, Physics and Chemistry. John Wiley \& Sons.

Jaramillo-Londoño, J. C., \& Pinto-Coelho, R. M. (2010). Interaction between Hexarthra intermedia (Rotifera) and Bosmina longirostris (Cladocera): a case of opportunistic nutrition or interference competition?. Journal of Plankton Research, 32(6), 961-966.

Jaramillo-Londoño, J. C., \& Aguirre-Ramírez, N. J. (2012). Fluctuación de los ensambles planctónicos en la Ciénaga de Ayapel (Córdoba-Colombia) durante un ciclo semanal. Revista Ingenierías Universidad de Medellín, 11(21), 63-76.

Junk, W. J. (1993). Wetlands of tropical south America. In Wetlands of the world: Inventory, ecology and management Volume I, Springer, Dordrecht. 679-739.

Kalff, J. (2002). Limnology. Prentice Hall, Prentice Hall, Upper Saddle River, NJ.

Kappelle, M., \& Horn, S. P. (2016). The Paramo ecosystem of Costa Rica's highlands. Costa Rican Ecosystems, 492-523.

Klug, J. L. (2002). Positive and negative effects of allochthonous dissolved organic matter and inorganic nutrients on phytoplankton growth. Canadian Journal of Fisheries and Aquatic Sciences, 59(1), 85-95.

Komárek, J. (1974). The morphology and taxonomy of crucigenoid algae (Scenedesmaceae, Chlorococcales). Archiv für Protistenkunde 116: 1-74.

Koste, W. (1978). Rotatoria, Die Rädertiere Mitteleuropas Ein Bestimmungswerk, Begründet von Max Voigt Überordnung Monogononta. I Textband. Gebrüder Borntraeger, Berlin, Stuttgart. 672p and II Textband. 234p.

Komarek, J. (1983). Contribution to the chlorococcal algae of Cuba. Nova Hedwigia: Zeitschrift fur Kryptogamenkunde. 37: 65-180.

Komárek, J. \& Foot, B. (1983). Das Phytoplankton des Sübwassers Systematik und Biologie. 7. Teil: Chlorophyceae (Grünalgen) Ordnung: Chlorococcales. Pp. 1-1044. In: H.J. Elster. \& W. Ohle, (eds.). Die Binnengewässer. Stutgart, Begründet von August Thienemann.

Koste, W., \& Shiel, R. J. (1987). Rotifera from Australian inland waters. II. Epiphanidae and Brachionidae (Rotifera: Monogononta). Invertebrate Systematics, 1(7), 949-1021.

Komárek, J., Anagnostidis, K. C., \& Cyanoprokaryota, I. (1999). 1. Teil: Chroococcales. Süsswasserflora von Mitteleuropa, 19(1), 548.

Komárek, J., \& Anagnostidis, K. (2005). Süßwasserflora von Mitteleuropa, bd. 19/2: Cyanoprokaryota:
Oscillatoriales (Vol. 19). Spektrum Akademischer Verlag.

Kruk, C., Peeters, E. T., Van Nes, E. H., Huszar, V. D. M., Costa, L. S., \& Scheffer, M. (2011). Phytoplankton community composition can be predicted best in terms of morphological groups. Limnology and Oceanography, 56(1), 110-118.

Kudo, R. R. (1985). Protozoología. 8. impresión. Editorial Continental. S. A., México D. F.

Lasso, C. A., Gutiérrez, F. D. P., \& Morales, B. (2014). Humedales interiores de Colombia: identificación, caracterización y establecimiento de límites según criterios biológicos y ecológicos. Instituto de Investigación de Recursos Biológicos Alexander von Humboldt.

Li, W., Xu X., Yao J., Tanaka N., Nishimura O., \& Ma H. (2019). Science of the Total Environment Combined effects of elevated carbon dioxide and temperature on phytoplankton-zooplankton link: A multi-influence of climate change on freshwater planktonic communities. 658: 1175-1185. doi: 10.1016/j.scitotenv.2018.12.180

Likens, G. E. (Ed.). (2010). Lake ecosystem ecology: a global perspective. Academic Press.

Llames, M. E., \& Zagarese H. E. (2009). Lakes and reservoirs of South America. 533-543.

López-Martínez, M. L., Jurado-Rosero, G. A., Páez-Montero, I. D., \& Madroñero-Palacios, S. M. (2017). Estructura térmica del Lago Guamués, un lago tropical de alta montaña. Revista Luna Azul, (44), 94-119.

Mello Brandao, L. P., Brighenti, L. S., Staehr, P. A., Asmala, E., Massicotte, P., Tonetta, D., ... Bezerra-Neto, J. F. (2018). Distinctive effects of allochthonous and autochthonous organic matter on CDOM spectra in a tropical lake. Biogeosciences, 15(9), 2931-2943. https://doi.org/10.5194/bg-15-2931-2018

Montoya, Y. M., \& Aguirre, N. (2009). Estado del arte de la limnología de lagos de planos inundables (Ciénagas) en Colombia. Gestión y Ambiente, 12(3), 85-106.

Montoya, Y., \& Aguirre, N. (2010). Dinámica de la producción primaria fitoplanctónica en un lago tropical (Ciénaga Escobillas) a lo largo del pulso de inundación. Medellin: Facultad de Ingeniería de la Universidad de Antioquia.76-89.

Montoya-Moreno, Y. M., \& Aguirre, N. (2012). Aproximación multivariada a la dinámica del ensamblaje algal epifítico en un sistema de planos inundables tropical. Revista Institucional Universidad Tecnológica del Chocó Investigación Biodiversidad y Desarrollo, $31(2)$.

Montoya-Moreno, Y., Sala, S. E., Vouilloud, A. A., \& Aguirre Ramírez, N. J. (2012). Diatomeas 
(Bacillariophyta) perifíticas del complejo cenagoso de Ayapel, Colombia. I.

Montoya-Moreno, Y. y Aguirre N. (2013). Dinámica del ensamblaje algal epifítico en el sistema de planos inundables de Ayapel a través del pulso de inundación. Revista U.D.C.A Actualidad y Divulgación Cientifica 16(2): 491-500.

Montoya-Moreno, Y., Sala, S., Vouilloud, A., Aguirre, N., \& Plata-Díaz, Y. (2013). Lista de las diatomeas de ambientes continentales de Colombia. Biota Colombiana, 14(2).

Morales-Rivas, M., Otero Garcia, J., Hammen, T. V. D., Torres Perdigón, A., Cadena Vargas, C. E., Pedraza Peñaloza, C. A., ... \& Posada Gilede, E. (2007). Atlas de páramos de Colombia. Instituto de Investigación de Recursos Biológicos Alexander von Humboldt.

Moritz, C. , Meynard, C. N. , Devictor, V. , Guizien, K. , Labrune, C. , Guarini, J.-M. , \& Mouquet, N. (2013). Disentangling the role of connectivity, environmental filtering, and spatial structure on metacommunity dynamics. Oikos, 122, 1401-1410.

Muñoz-López, C., Aranguren-Riaño, N., \& Duque, S. (2017). Morfología funcional del fitoplancton en un lago de alta montaña tropical: Lago de Tota (Boyacá-Colombia). Revista de Biología Tropical, 65(2), 669-683.

Nogrady, T., \& Segers, H. (2002). Rotifera Volume 6: Asplanchnidae, Gastropodidae, Lindiidae, Microcodidae, Synchaetidae, Trochosphaeridae and Filinia. Guides to the identification of the microinvertebrates of the continental waters of the world 18. Leiden, The Netherlands: Backhuys Publishers.

Nogrady, T., Wallace R. L., \& Snell T.W. (1993). Rotífera. Volume 1: Biology, ecology and systematics. $S P B$ Academic Publishing.

Nogrady, T., Pourriot R., \& Segers H. (1995). Rotifera, Volume 3: The Notommatidae and the Scaridiidae. Guides to the identification of the microinvertebrates of the continental waters of the world 8. SPB Academic Publishing. Amsterdam.

Olson, D. M., Dinerstein, E., Wikramanayake, E. D., Burgess, N. D., Powell, G. V., Underwood, E. C., ... \& Loucks, C. J. (2001). Terrestrial Ecoregions of the World: A New Map of Life on Earth A new global map of terrestrial ecoregions provides an innovative tool for conserving biodiversity. BioScience, 51(11), 933-938.

Osorio-Ávila, F. J., \& Manjarres-García, G. A. (2015). Ficoperifíton asociado a macrófitas en la ciénaga Cerro de San Antonio, Magdalena-Colombia. Intropica, 74-83.

Parra, O., González, M., Dellarossa, V., Rivera, P., \& Orellana, M. (1982a). Manual taxonómico del fitoplancton de aguas continentales. Con especial referencia al fitoplancton de Chile I: Cyanophyceae. Universidad de Concepción. Chile.

Parra, O., González, M., Dellarossa, V., Rivera, P., \& Orellana, M. (1982b). Manual taxonómico del fitoplancton de aguas continentales con especial referencia al fitoplancton de Chile II. Crysophyceae. Universidad de Concepción. Chile.

Parra, O., González, M., Dellarossa, V., Rivera, P., \& Orellana, M. (1982c). Manual taxonómico del fitoplancton de aguas continentales con especial referencia al fitoplancton de Chile III. Cryptophyceae-Dinophyceae-Euglenophyceae. Universidad de Concepción. Chile.

Parra, O., González, M., Dellarossa, V., Rivera, P., \& Orellana, M. (1983a). Manual taxonómico del fitoplancton de aguas continentales con especial referencia al fitoplancton de Chile V. Chlorophyceae. Parte I, Volvocales.Universidad de Concepción. Chile.

Parra, O., González, M., Dellarossa, V., Rivera, P., \& Orellana, M. (1983b). Manual taxonómico del fitoplancton de aguas continentales con especial referencia al fitoplancton de Chile V. Chlorophyceae. Parte II, Zygnematales.Universidad de Concepción. Chile.

Patrick, R. \& Reimer C.W. (1966). The diatoms of the United States (exclusive of Alaska and Hawaii). Monographs of the Academy of natural Sciences of Philadelphia, 13, 1-688.

Pava, E., Carrasquilla, J., \& López, W. (2006). Caracterización de la comunidad fitoplanctónica de un plano de inundación del río Sogamoso en la cuenca media del río Magdalena (Ciénaga de San Silvestre, Colombia). Intropica, 43-57.

Pedraza, G. S., Márquez, G. M., \& García, L. C. G. (1989). Aspectos hidro-limnologicos en las ciénagas de chucuri y aguas negras (Magdalena medio, Colombia) durante un ciclo anual. Acta Biológica Colombia$n a, 1(5), 9-22$.

Peña, E. J., Palacios, M. L., \& Ospina-Álvarez, N. (2005). Algas como indicadores de contaminación. Universidad del Valle, Programa Editorial, Colección Ciencias Físicas, Exactas y Naturales. Santiago de Cali, Colombia, 172.

Phan, D. D., Nguyen, V. K., Le, T. N. N., Dang, N. T., \& Ho, T. H. (2015). Identification handbook of freshwater zooplankton of the Mekong River and its tributaries. Mekong River Commission, Vientiane, 207.

Pinilla, G. (2005). Ecología del fitoplancton en un lago amazónico de aguas claras (Lago Boa, Caquetá Medio, República de Colombia). U. Jorge Tadeo Lozano.

Pinilla, G. A., Canosa, A., Vargas, A., Gavilán, M., \& López, L. (2007). Acoplamiento entre las comunidades 
planctónicas de un lago amazónico de aguas claras (lago Boa, Colombia). Limnetica, 26(1), 053-65.

Pinilla, G. A., Duarte, J. D., \& Vega, L. V. (2010). Índice de estado limnológico (IEL) para evaluar las condiciones ecológicas de las ciénagas del canal del dique, Colombia. Acta Biológica Colombiana, 15(2), 169-188.

Ramírez, A., \& Viña, G. (1998). Limnología colombiana: aportes a su conocimiento y estadísticas de análisis. Fundación Universidad de Bogotá Jorge Tadeo Lozano.

Reid, J. W. (1985). Chave de identificação e lista de referências bibliográficas para as espécies continentais sulamericanas de vida livre da ordem Cyclopoida (Crustacea, Copepoda). Instituto de Biociências, Universidade de São Paulo.

Reynolds, C. S. (1984). Phytoplankton periodicity: the interactions of form, function and environmental variability. Freshwater Biology, 14(2), 111-142.

Reynolds, C. S. (2008). A changing paradigm of pelagic food webs. International Review of Hydrobiology, 93(4-5), 517-531.

Reynolds, C. S., Huszar, V., Kruk, C., Naselli-Flores, L., \& Melo, S. (2002). Towards a functional classification of the freshwater phytoplankton. Journal of Plankton Research, 24(5), 417-428.

Ricaurte, L. F., Patiño, J. E., Zambrano, D. F. R., Arias-G, J. C., Acevedo, O., Aponte, C., ... \& EstupinanSuarez, L. M. (2019). A Classification System for Colombian Wetlands: an Essential Step Forward in Open Environmental Policy-Making. Wetlands, 1-20.

Rivera-R, C., Solano-M, D., Zapata-A, A., \& Donato-R, J. (2005). Phytoplankton diversity in a tropical high mountain lake. Internationale Vereinigung für theoretische und angewandte Limnologie: Verhandlungen, 29(1), 418-421.

Rivera, O. D. (2001). Páramos de Colombia. Banco de Occidente. I/M Editores. Imprelibros, Santiago de Cali, Colombia.

Rondón, C. A. R., Zapata, A. M., Perez, D., Morales, Y., Ovalle, H., \& Alvarez, J. P. (2010). Caracterización limnológica de humedales de la planicie de inundación del río Orinoco (Orinoquía, Colombia). Acta Biológica Colombiana, 15(1), 145-166.

Roldán, G. y Ramírez, J.J. (2008). Fundamentos de limnología neotropical. Editorial Universidad de Antioquia. Segunda edición.

Roldán-Pérez, G. (2009). Desarrollo de la limnología en Colombia: cuatro décadas de avances progresivos. Actualidades Biológicas, 31(91), 227-237.
Ruttner-Kolisko, A. (1974). Plankton Rotifers. Biology and Taxonomy. Die Binnengewässer 26/1, suppl., Stuttgart.

Sala, S. E., Ramírez, J. J., Plata Y. (2008). Diatoms from lentic and lotic systems in Antioquia, Chocó and Santander Departments in Colombia. Revista de Biología Tropical, 56(3), 1159-1178.

Sala, S. E., Vouilloud, A. A., Plata-Díaz, Y., Pedraza, E., \& Pimienta, A. (2015). Taxonomía y distribución de diatomeas epilíticas registradas por primera vez en Colombia. I: Taxonomy and distribution of epilithic diatoms reported for the first time in Colombia. I. Caldasia, 37(1), 125-141.

Segers, H. (1995). Rotifera. Volume 2: The Lecanidae (Monogonota). Guides to the identification of the microinvertebrates of the continental waters of the world 6. SPB, La Haya, Holanda.

Sendacz, S., \& Kubo E. (1982). Copepoda (Calanoida e Cyclopoida) de reservatórios do Estado de São Paulo. B. Boletim do Instituto de Pesca. 9: 51-89.

Shield, R. J., \& Kosté, W. (1992). Rotifera from Australian inland waters VIII. Trichocercidae (Monogononta). Royal Society of South Australia Inc, 116(1), 1-27.

Shield, R. J., \& Koste, W. (1993). Rotifera from Australian inland waters. IX. Gastropodidae, Synchaetidae, Asplanchnidae (Rotifera: Monogononta). Transactions of the Royal Society of South Australia, 117(1), 111-139.

Siemensma, F. J. (2019). Microworld, world of amoeboid organisms. World-wide electronic publication, Kortenhoef, the Netherlands.

Silva, S. R., Pinheiro, D. G., Meer, E. J., Michael, T. P., Varani, A. M., \& Miranda, V. F. (2017). The complete chloroplast genome sequence of the leafy bladderwort, Utricularia foliosa L.(Lentibulariaceae). Conservation Genetics Resources, 9(2), 213-216.

Sistema de Información sobre Biodiversidad de Colombia [SiB Colombia]. (2019). Portal de datos. https://sibcolombia.net/. Accessed July 10, 2019.

Solís-Parra, J. S., \& Criales-Hernández, M. I. (2016). Capture and selectivity of zooplankton by Utricularia foliosa (Lentibulariaceae) in the Ciénaga de Paredes, Santander, Colombia. Revista de Biología Tropical, 64(3), 1297-1310.

Starmach, K. (1983). Euglenophyta - Eugleniny. Vol. 3 pp. 594. Warszawa: Panstwowe Wydawnictwo Naukowe.

Suárez, E., Reid J., Lliffe T., \& Fiers F. (1996). Catálogo de los copépodos (Crustácea) continentales de la península de Yucatán, México. Colegio de la frontera sur, Chatumal, México. 
Tell, G., \& Conforti V. (1986). Euglenophyta pigmentadas de la Argentina. Facultad de Ciencias Naturales de la UBA. Buenos Aires. 301 pp.

Thorp, J. H., \& Covich, A. P. (2001). An overview of freshwater habitats. Ecology and Classification of North American Freshwater Invertebrates', 2nd edn. (Eds J. Thorp and AP Covich.) pp, 19-41.

Tuchman, N. C., 1996. The role of heterotrophy in benthic algae. In: Stevenson, R. J., Bothwell, M. L., Lowe, R. L., \& Thorp, J. H. (1996). Algal ecology: Freshwater benthic ecosystem. Academic press.

Tuchman, N. C., Schollett, M. A., Rier, S. T., \& Geddes, P. (2006). Differential heterotrophic utilization of organic compounds by diatoms and bacteria under light and dark conditions. In Advances in Algal Biology: A Commemoration of the Work of Rex Lowe (pp. 167177). Springer, Dordrecht.

Tyler, J. E. (1968). The secchi disc. Limnology and Oceanography, 13(1), 1-6.

Urabe, J., Togari, J. U. N., \& Elser, J. J. (2003). Stoichiometric impacts of increased carbon dioxide on a planktonic herbivore. Global Change Biology, 9(6), 818-825.

Vila, I., \& Mühlhauser, H. A. (1987). Dinâmica de lagos de altura, perspectivas de investigado. Arch. Biol. Med. Exp, 20, 95-103.
Villabona-González, S. L., Aguirre, N. J., \& Estrada, A. L. (2011). Influencia de las macrófitas sobre la estructura poblacional de rotíferos y microscrustáceos en un plano de inundación tropical. Revista de Biología Tropical, 59(2), 853-870.

Webb, C. O., Ackerly, D. D., McPeek, M. A., \& Donoghue, M. J. (2002). Phylogenies and community ecology. Annual Review of Ecology and Systematics, 33(1), 475-505.

Wieczorek, J., Döring M., De Giovanni R., Robertson T., \& Vieglais D. (2009). Darwin Core. http://rs.tdwg. org/dwc

Wilhelm, S., \& Adrian, R. (2008). Impact of summer warming on the thermal characteristics of a polymictic lake and consequences for oxygen, nutrients and phytoplankton. Freshwater Biology, 53(2), 226-237.

Woodward, G., Perkins, D. M., \& Brown, L. E. (2010). Climate change and freshwater ecosystems: impacts across multiple levels of organization. Philosophical Transactions of the Royal Society B: Biological Sciences, 365(1549), 2093-2106.

WoRMS Editorial Board. (2019). World Register of Marine Species. Avalible from http://www.marinespecies. org al VLIZ.

Zapata-Anzola, A. M., Rivera-Rondón, C. A., \& DonatoRondón, J. C. (2006). Dynamics of photosynthetic pigments in an Andean lake in Colombia. Lakes \& Reservoirs: Research \& Management, 11(1), 29-38.

\section{See Digital Appendix at: / Ver Apéndice digital en: revistas.ucr.ac.cr}

